Bangladesh J. Plant Taxon. 17(2): 113-120, 2010 (December)

(C) 2010 Bangladesh Association of Plant Taxonomists

\title{
PHYLOGENETIC RELATIONSHIPS AMONG THE TAXA OF THE GENUS JOHRENIA DC. (APIACEAE) FROM TURKEY BASED ON MOLECULAR METHOD
}

\author{
Bekir Dogan*, Ahmet Duran ${ }^{1}$, Yavuz BaGCl$^{2}$, Muhittin Dinc ${ }^{1}$, \\ Esra Martin ${ }^{1}$, Ozlem Cetin $^{1}$ and Meryem Ozturk ${ }^{1}$ \\ Selcuk University, Education Faculty, Department of Science Education, \\ 42090, Konya, Turkey \\ Keywords: Johrenia; Dichoropetalum; Apiaceae; Taxonomy; ISSR; Turkey.
}

\begin{abstract}
In the present study, ISSR markers were employed to determine the phylogenetic relationships among the taxa of Johrenia. The genera Angelica and Xanthogalum were selected as outgroups. Unweighted pair group method with arithmetic mean (UPGMA) and Principal Coordinate Analyses were conducted to view the molecular relationships. Johrenia alpina, J. depauperatum and $J$. aurea are transferred to the genus Dichoropetalum. The infrageneric and intergeneric phylogenetic relationship among the Johrenia and Dichoropetalum genera are determined.
\end{abstract}

\section{Introduction}

The Apiaceae family is represented by approximately 400 genera and 3500 species worldwide (Constance, 1971; Pimenov and Leonov, 1993). The family consists of 102 genera and 434 species in Turkey (Erik and Tarkkahya, 2004). The Apiaceae includes many commonly grown vegetables (carrot, parsnip) and condiments (chervil, cumin, parsley, dill). They owe their distinctive flavour largely to diverse essential oil compounds in the fruits, seeds and leaves. The family also encompasses widespread weeds and toxic plants (Downie et al., 2000).

A molecular approach has contributed much to understanding the evolutionary relationships of Apiaceae. Phylogenetic analyses of the family using chloroplast DNA (cpDNA) sequences (Downie et al., 1996), cpDNA restriction sites (Plunkett and Downie, 1999), and nuclear ribosomal DNA internal transcribed spacer (ITS) sequences (Downie and Katz-Downie, 1996) provided an alternative classification of Drude (1898). Revision based on molecular data provide better resolution of the systematic positions. The taxonomic problems at the species level have begun started to be solved with DNAbased molecular analyses which are not affected by environmental conditions, in contrast to the phenotypical analyses.

*Corresponding author. E-mail: < bdogan@selcuk.edu.tr>. ${ }^{1}$ Selcuk University, Education Faculty, Department of Biology Education, Konya 42090, Turkey. ${ }^{2}$ Selcuk University, Faculty of Science and Literature, Department of Biology, Konya 42031, Turkey. 
Probably, the centre of the genetic diversity of the genera Johrenia and Dichoropetalum are in Anatolia. Johrenia is represented by nine taxa in Turkey, namely, Johrenia selinoides, J. porteri, J. dichotoma subsp. dichotoma, J. dichotoma subsp. sintenisii, J. tortuosa, J. polyscias, J. alpina, J. berytea, and J. aurea (Chonberlair, 1972). Five of these species are endemic to Turkey, viz J. selinoides, J. dichotoma subsp. sintenisii, J. alpina, J. berytea, and J. polyscias. The sample of J. dichotoma subsp. sintenisii was collected by G. Post 120 years ago and was only known from the type locality in Mardin province. Johrenia aurea species was collected 150 years ago which was only known from the type locality on Aslandağ mountain in Kayseri province (Chamberlain, 1972).

Johrenia was described first by Candolle (1829) based on J. dichotoma DC. Later, Dichoropetalum Fenzl, based on D. alpinum Fenzl, was described (Fenzl, 1842) but soon after sunk by its author into synonymy with Johrenia (Fenzl, 1843). The basis for the modern Johrenia taxonomy was laid by Boissier (1844), who placed 10 species in Johrenia, and divided them into two informal groups. The first contains six species ( $J$. selinoides, J. dichotoma, J. fungosa, J. graeca, J. alpina and J. berytea). The second group was again subdivided into two subgroups. The first subgroup comprises $J$. candollei, J. platycarpa, and the other subgroup contains $J$. aurea and J. juncea. Drude (1898) maintained Boissier's classification of the genus. Bornmüller (1930) compiled a synopsis of the Johrenia species and included descriptions of some new species, among which J. polyscias is adopted in Turkish flora (Chamberlain, 1972).

Pimenov et al. (2007) made a comprehensive taxonomic analysis of Dichoropetalum, Johrenia, Zeravschania and other related genera of Apiaceae based on 32 morphological diagnostic characters. According to results from their comparative multivariate analysis, 28 new nomenclatural combinations are validated and lectotypes are designated for several names. From the genus Johrenia, Pimenov et al. (2007) transferred J. alpina, J. aromatica, J. berytea, J. aurea, J. golestanica, J. paucijuga, J. platycarpa and $J$. ramosissima into the genus Dichoropetalum. In addition, Johrenia westii was transferred to the genus Ferulago. Transferred species J. alpina, J. berytea and J. aurea are endemic to Turkey. According to the latest taxonomic analysis on some of the genera in Apiaceae family, the Johrenia and Dichoropetalum genera are represented by six taxa and three species respectively in Turkey. These taxa are as follows: Johrenia selinoides, J. porteri, J. dichotoma subsp. dichotoma, J. dichotoma subsp. sintenisii, J. tortuosa, J. polyscias in Johrenia genus; Dichoropetalum alpinum, D. aureum and D. depauperatum (Syn. J. berytea) in Dichoropetalum genus (Pimenov et al., 2007).

Currently morphological revisions of various plant taxa are often supported by molecular data (APG, 2003). As compared with morphological data, DNA data are not influenced by the environmental conditions in which the plants have grown; hence they serve as a powerful tool in resolving taxonomical and systematical problems. 
The aim of our study was to determine the infrageneric and intergeneric phylogenetic relationship among the Johrenia and Dichoropetalarum genera emplyomg ISSR method. Also, we selected Angelica sylvestris (M. Bieb.) Sprengel and Xanthogalum purpurascens Lallem. to resolve their controversial status by using a DNA based molecular marker system.

\section{Materials and Methods}

Plant materials: Johrenia and Dichoropetalum specimens were collected by the authors from Amasya, Mersin, Adana, Niğde, Kahramanmaraş, Bursa, Konya, Osmaniye and Kayseri provinces between of 2003-2008 (Fig. 1). The Flora of Turkey (Chamberlian, 1972), Flora Iranica (Rechinger, 1987), and Flora Europaea (Tutin, 1968), were used to identify the collected plant samples. Specimens are kept in Selçuk University Education Faculty Herbarium. The specimens' localities (Fig. 1) and examined representative specimens are in the appendix. The genera Angelica and Xanthogalum were selected as outgroups. These genera are closest to Johrenia in respect to phylogeny in Turkish flora.

DNA isolation: Nuclear DNA was isolated from leaves both from herbarium and fresh materials using CTAB method (Sambrok et al., 1989). Total DNA was obtained from 50-75 mg dried leaf tissue from 10 different individuals. DNAs were isolated with the Easy Nucleic Acid Isolation Kit (OMEGA) and concentrations were determined by Nanodrop. Sample DNAs were diluted to $25 \mathrm{ng} / \mu \mathrm{l}$. Stock DNAs were kept at $-86^{\circ} \mathrm{C}$.

ISSR amplifications: ISSR primers (Galvan et al., 2003) were amplified in a PCR thermal cycler. The characteristics of the primers used are given in Table 1. Each PCR reaction contained $25 \mu \mathrm{l}$ containing $2.5 \mu \mathrm{l}$ PCR buffer $(10 \mathrm{mM}$ TRIS/50 mM KCl buffer, $\mathrm{pH}$ 8.0), $3 \mu \mathrm{l} 25 \mathrm{mM} \mathrm{MgCl}, 0.5 \mu \mathrm{l}$ of each primer, $0.5 \mu 1$ of dNTP mix, $0.4 \mu 1$ Taq DNA polymerase, $4 \mu \mathrm{l}$ of each DNA and $14.1 \mu \mathrm{l}$ distilled water. After a pre-denaturation step of $3 \mathrm{~min}$ at $94{ }^{\circ} \mathrm{C}$, amplification reactions were cycled 40 times at $94^{\circ} \mathrm{C}$ for $1 \mathrm{~min}$, at annealing temperature (Table 1) for $1 \mathrm{~min}$ and $72^{\circ} \mathrm{C}$ for $1 \mathrm{~min}$ and a final extension was allowed for $10 \mathrm{~min}$ at $72^{\circ} \mathrm{C}$ in an Eppendorf Mastercycler Gradient Thermocycler. Upon completion of the reaction, $15 \mu \mathrm{l}$ aliquots of the PCR products were mixed with $3 \mu \mathrm{l}$ of loading dye (50\% glycerol, $0.25 \%$ bromophenol blue and $0.15 \%$ xylene cyanol) and loaded onto a $2 \%$ agarose, $1 \mathrm{X}$ TRIS-Borate-EDTA gel and electrophoriesed at $4 \mathrm{~V} \mathrm{~cm}$. Amplified fragments were visualized under a UV transiluminator and photographed using a gel documentation system (Vilbert Lourmat, Infinity model).

Data analysis: All the fragments amplified were treated as dominant genetic markers. Each DNA band generated was visually scored as an independent character or locus (' 1 ' for presence and ' 0 ' for absence). Qualitative differences in band intensities were not considered. Every gel was scored in triplicate (independent scorings) and only the fragments consistently scored were considered for analysis. A rectangular binary data 
matrix was prepared and all the data analysis was performed using the Numerical Taxonomy System, NTSYS-pc version 2.02 (Applied Biostatistic, Exeter Software, Setauket, New York, USA). Similarity coefficient method was used. In cluster analysis of the samples the unweighted pair-group method with arithmetic mean (UPGMA) procedure was followed (Rohlf, 1992). Genetic distances calculated with the Simple Mathing coefficient. In order to determine the ability of ISSR data to display the interrelationships among the samples analysis was conducted using NTSYS-pc package.

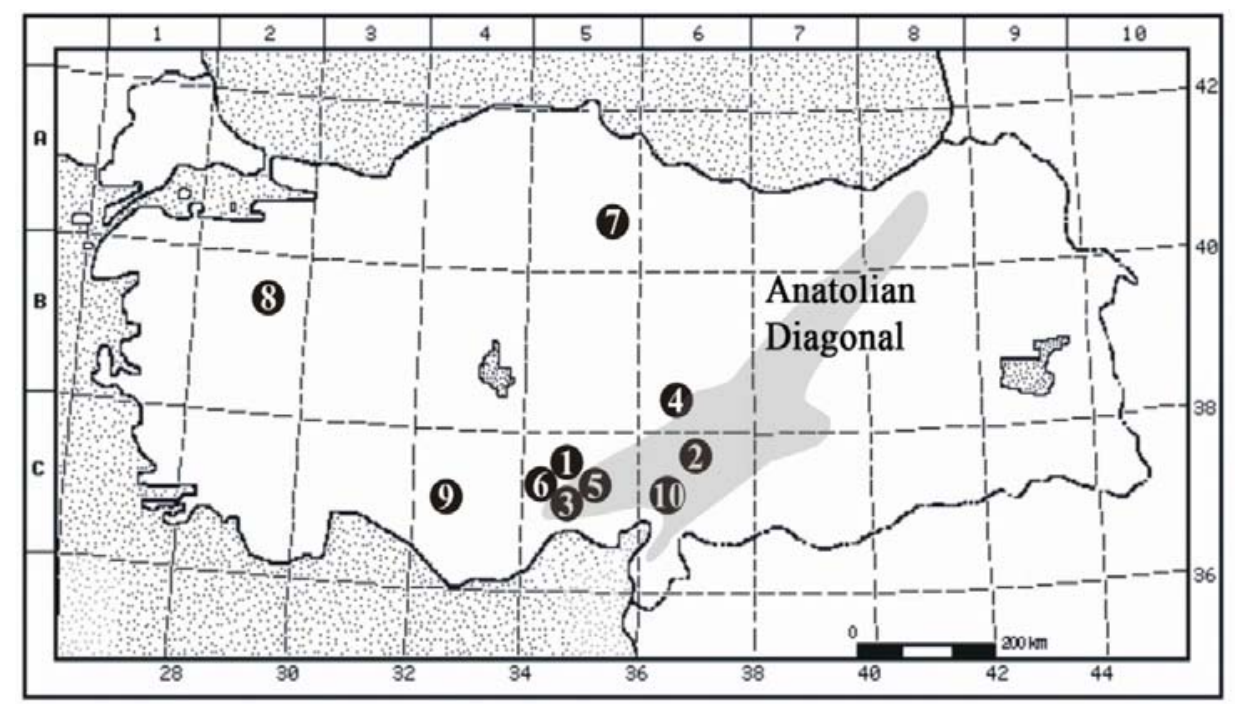

Fig. 1. Distribution map of the examined specimens; 1. Dichoropetalum aytachii, 2. D. depauperatum, 3. D. alpinum, 4. Johrenia porteri, 5. J. selinoides, 6. J. dichotoma, 7. J. polyscias, 8. J. tortuosa, 9. Xanthogalum purpurascens, 10. Angelica sylvestris.

\section{Results and Discussion}

From an initial screening of 25 ISSR primers, nine primers revealed high levels of polymorphisms. These primers generated 90 highly polymorphic fragments that were consistently amplified in repeated experiments. The GC percentages of the selected primers were within the range of $38.9-66.7 \%$ (five of them being $52.6 \%$ ). In total, the average number of polymorphic fragments per primer used was roughly 11. Genetic distances calculated with the SM coefficient ranged from 0.46 to 0.99 .

As a result of the evaluation of the ISSR data, Dichoropetalum depauperatum showed $95 \%$ similarity with and D. aytachii.

The clade composed of J. dichotoma and J. porteri are very similar according to the morphological characters. These similarities are supported with the ISSR data and these species show much more similarity in the dendogram than any other species (Fig. 2). 
Pimenov et al. (2007) selected 33 morphological characters for phenetic analyses of Johrenia, Dichoropetalum, Zeravschania and related genera. Selected characters were used to perform UPGMA analysis, and the resulting phenogram showed the relationships among Johrenia, Dichoropetalum, Zeravschania, and related genera. In the phenogram, three major groups matched with one of the three genera. The molecular dendogram of the genera Dichoropetalum and Johrenia showed parallelism among the major groups like the phenogram of Johrenia, Dichoropetalum, Zeravschania genera of Pimenov et al. (2007).

Table 1. ISSR primers used in this study and their specifications.

\begin{tabular}{llcccc}
\hline PRIMER & PRIMER SEQUENCE & $\mathrm{T}_{\text {melting }}\left({ }^{0} \mathrm{C}\right)$ & $\mathrm{SIZE}(\mathrm{bp})$ & $\mathrm{GC} \%$ & $\mathrm{~T}_{\text {annealing }}$ \\
\hline ISSR M8 & ACACACACACACACACACG & 56.7 & 19 & 52.6 & 56 \\
ISSR M12 & GACACGACACGACACGACAC & 61.4 & 20 & 60 & 60 \\
ISSR M15 & CACACACACACACACAAG & 53.7 & 18 & 50 & 53 \\
ISSR N2 & GTGGTGGTGGTGGTG & 53.3 & 15 & 66.7 & 52 \\
ISSR F1 & GAGCAACAACAACAACAA & 49.1 & 18 & 38.9 & 49 \\
ISSR F2 & CTCGTGTGTGTGTGTGTGT & 56.7 & 19 & 52.6 & 56 \\
ISSR F5 & AGAGAGAGAGAGAGAG & 49.2 & 16 & 50 & 49 \\
ISSR F6 & CCACCACCACCACCA & 53.3 & 15 & 66.7 & 53 \\
ISSR F7 & ACACACACACACACAC & 49.2 & 16 & 50 & 48 \\
\hline
\end{tabular}

The present study based on ISSR data revealed four clades, each clade matching with one of the four genera, viz. Johrenia, Dichoropetalum, Angelica and Xanthogalum. The genus Angelica with Xanthogalum, and Dichoropetalum with Johrenia shows much more molecular phylogenetic similarity. There is a correlation between the morphologic diagnostic characters and molecular taxonomic classification.

The concept of the "Diagonal" was first proposed by Davis (1971), who defined it as an oblique belt running from the north east, south to the Anti-Taurus; it then divides into two, with one branch to the Amanus (Amanos Mountains), and the other to the Cilician Taurus (Fig. 1). Thirty three percent of the total species growing in Turkey are found along the diagonal, while 5\% are more or less restricted to it (Ekim and Güner, 1986).

The spread of genus Dichoropetalum is on the Anatolian diagonal (Fig. 1). The genus occurs in the Anti-Taurus region and branch (Aladağ, Amanos and Bolkar mountains) of the Anatolian diagonal. In Anatolia, almost all mountain peaks so far examined abound in endemics (Zohary, 1973). All species of Dichoropetalum are grown on mountain peaks and endemics in Anatolia. The Anatolian Diagonal and its adjacent areas are one of the most important centers of genetic diversity in Turkey. The Amanos mountain range is an interesting area, occupying an intersection of the Mediterranean phytogeographical 
region and the Anatolian Diagonal, with many Euro-Siberian phytogeographical region enclaves (Ekim and Güner, 1986). The area is very rich in paleo and neo endemic plants.

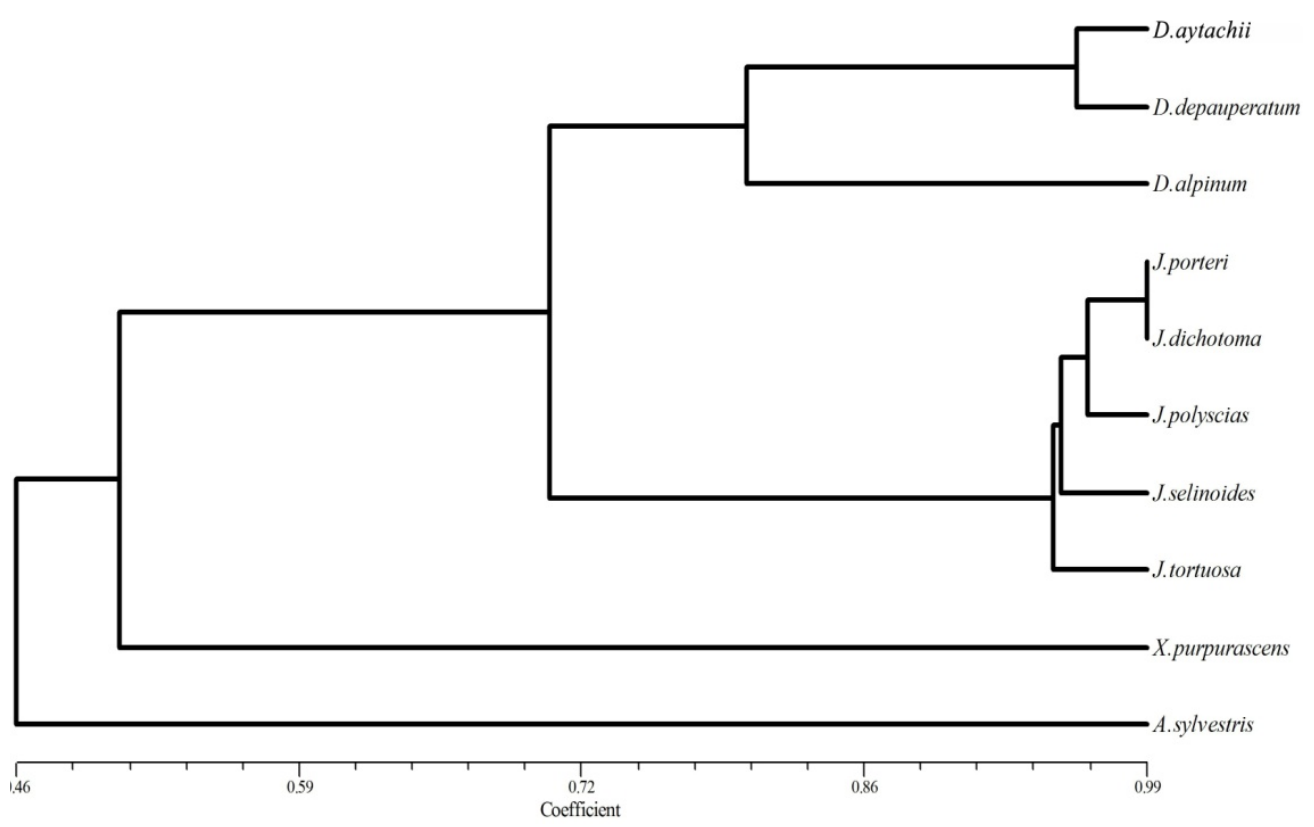

Fig. 2. Dendogram showing genetic relationship of Johrenia, Dichoropetalum, Angelica and Xanthogalum species based on ISSR markers.

An interesting Dichoropetalum specimen, D. aytachii, (A. Duran 7699, Bagci \& Dinc) was collected from Aladağlar Mountain (Niğde) in 2007. It is rather different specimens in Dichoropetalum genus. On the specimen is required more comprehensive morphological, anatomical, palynological and cytotaxonomical studies. The specimen of the genus Dichoropetalum examined with other samples, and its species placed in different clade in dendogram (Fig. 2). The related species were clearly separated by the principal coordinate analysis (Fig. 3).

Although the genus Johrenia is distributed primarily in the East Mediterranean region, some species maintain an interrupted spread in the ecotone zone in Central Anatolia. They grow on the Anatolian diagonal or western side of the diagonal except for J. dichotoma ssp. sintenisii. This taxon is only known from the type locality and is a very local endemic. This genus represents six species in the world and five species in Turkey (J. distans spread in Greece and F.Y.R. Macedonia). Four species of Johrenia endemic to Turkey are found on the Anatolian Diagonal. Taxa of Johrenia are poorly occurring and have local population in Anatolia. Opposite to the genus Dichoropetalum, the genus Johrenia is distributed in the lowest altitude of the mountains in Turkey. 


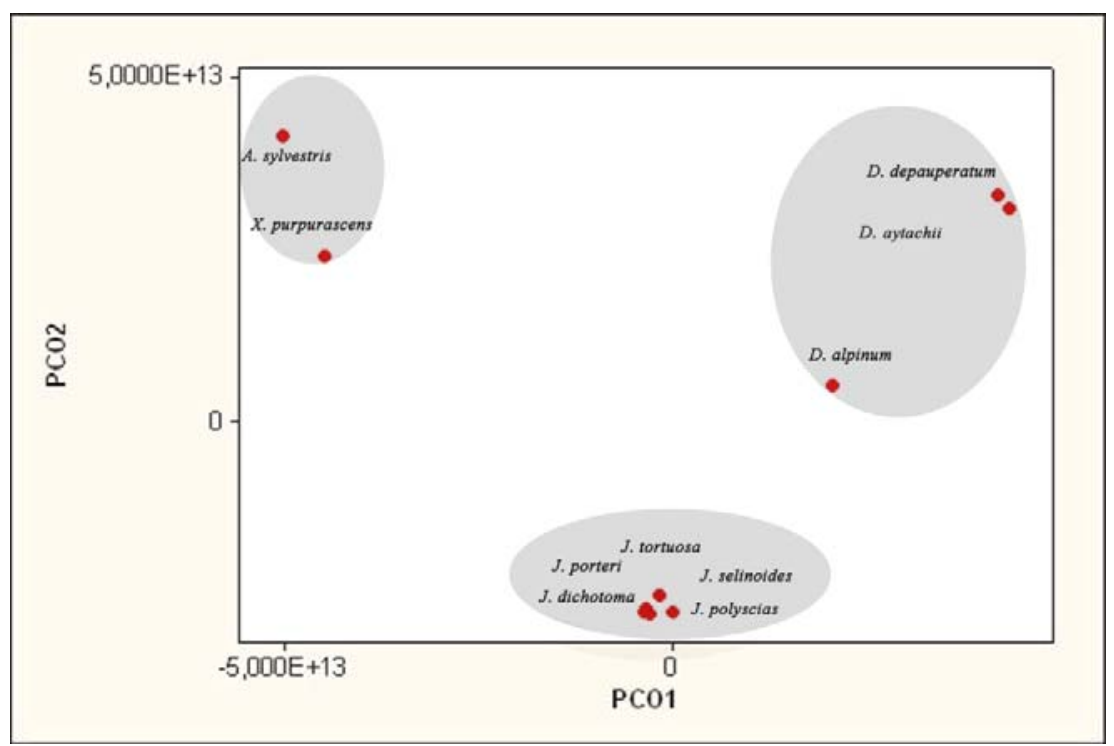

Fig. 3. Principal coordinate analysis of Johrenia, Dichoropetalum, Angelica and Xanthagalum species.

As a result the Johrenia and Dichoropetalum taxa in Turkey are classified according to the molecular data. J. alpina, J. depauperatum and $J$. aurea species have been transferred to the genus Dichoropetalum. Therefore, Johrenia and Dichoropetalum contain five and three species, respectively as revealed from molecular phylogenetic studies.

\section{Acknowledgements}

We would like to thank to Selcuk University (BAP Project no: 05401075) for financial support during this study.

\section{Appendix}

EXAMINED REPRESENTATIVE SPECIMENS: - Dichoropetalum alpinum. C5 Mersin: Gülek, Maden road, Karlıboğaz, 2400 m, 10.08.2007, steppe, Duran et al., 7711, (Duran, Bağc1 \& Dinc) - D. depauperatum. C6 Kahramanmaraş: Göksun, Çardak, from Ericek village to Berit Mountain 2100-2400 m, 08.08.2007, steppe, Duran et al., 7687, - D. aytachii. C5 Niğde: Çamardı, Aladağlar, Emli mountain pass, 2100 m, 09.08.2007, calcareous slopes, 3800.844'N, 36²9.579'E Duran et al., 7699, - Johrenia porteri. B6 Kayseri: Sarız, between Yalak (Yeşilkent)-Körkuyu, 1450 m, 7.8.2007, Duran et al., 7686, - Johrenia selinoides. C5 Adana: Gülek mountain pass, between Akçatekir-Adana, $850 \mathrm{~m}, 10.08 .2007$, open forest, calcareous stony slopes, $37^{\circ} 13.271^{\prime} \mathrm{N}, 34^{\circ} 48.621^{\prime} \mathrm{E}$, Duran et al.,7708, - Johrenia dichotoma. C5 Mersin: Karakütük village, 700 m, 05.06.2007, roadsides, open machia, Duran et al., 7381, - Johrenia polyscias. A5 Amasya: Hartna

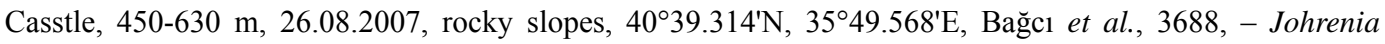
tortosa. B2 Bursa: Harmanc1k- Dursunbey road, 450 m, 21.07.2006, open Pinus brutia, Duran 7292. Xanthayalum purpuracens. C4 Konya: Hadim, Gevne valley, Beyreli village, 1300, 25.7.2003, streamside, Duran 6332. - Angelica sylvestris. C6 Osmaniye: Yarpuz, 850 m, 12.09.2003, wet places, Duran 6354. 


\section{References}

APG (Angiosperm Phylogeny Group). 2003. An update of the Angiosperm Phylogeny Group classification for the orders and families of flowering plants: APG II. Bot. J. Linn. Soc. 141: 399-436.

Boissier, P.E. 1844. Annales des Sciences Naturelles, Botanique sér. 3, 1: 304.

Bornmüller F. 1930. Repertorium Specierum Novarum Regni Vegetabilis. Centralblatt für Sammlung und Veroffentlichung von Einzeldiagnosen neuer Pflanzen. [Edited by Friedrich Fedde]. 28: 44.

Candolle, A.P. De. 1829. Collection de memoires 5. Memoire sur la famille d'Ombelliferes. -Paris \& Strasbourg.

Chamberlain, D.F. 1972. Johrenia DC. In: Davis, P.H. (ed.), Flora of Turkey and the East Aegean Islands, Vol. 4, Edinburgh University Press, Edinburgh, pp. 434-437,

Constance, L. 1971. History of the Classification of Umbelliferae (Apiaceae). In: Heywood, V. H. (ed.), The biology and chemistry of the Umbelliferae, Academic Press, London U.K. pp. 1-8.

Davis, P.H. 1971. Distribution patterns in Anatolia with particular reference to endemism. In: Plant Life of South West Asia, Davis, P.H \& Hedge, I.C. (eds.), Edinburgh, Botanical Society of Edinburgh, pp. 15-27

Downie, S.R. and Katz-Downie, D.S. 1996. A moleculer phylogeny of Apiaceae subfamily Apioideae: evidence from nuclear ribosomal DNA internal transcribed spacer sequences. Am. J. Bot. 83: 234-251.

Downie, S.R., Katz-Downie, D.S. and Cho, J. 1996. Phylogenetic analysis of Apiaceae subfamily Apioideae using nucleotide sequences from the chloroplast rpoC1 intron. Mol. Phylogenet. Evol. 6: 1-18.

Downie, S.R., Katz-Downie, D.S. and Spalik, K. 2000. A Phylogeny of Apiaceae Tribe Scandiceae: Evidence from Nuclear Ribosomal DNA Internal Transcribed Spacer Sequences. Am. J. Bot. 87: 76-95.

Drude, C.G.O. 1898. Umbelliferae, In: Engler, A. and Prantl, K. (eds.), Die natürlichen Pflanzenfamilien, vol. 3(8): 63-250. Wilhelm Engelmann, Leipzig, Germany.

Ekim, T. and Güner, A. 1986. The Anatolian Diagonal: fact or fiction?. Proceedings of the Royal Society of Edinburgh 89B, 69-77.

Erik, S. and Tarikahya, S. 2004. Türkiye Florası Üzerine, Kebikeç 17: 117-137.

Fenzl, E. 1842. Pugillus Plantarum Novarum Syriae et Tauri Occidentalis Primus.

Fenzl E. 1843. Flora Brasiliensis, enumeratio plantarum in Brasilia hactenus detectarum :quas suis aliorumque botanicorum studiis descriptas et methodo naturali digestas partim icone illustratas /ediderunt Carolus Fridericus Philippus de Martius et Augustus Guilielmus Eichler ; iisque defunctis successor Ignatius Urban.. Monachii et Lipsiae [Munich \& Leipzig] : R. Oldenbourg.

Galvan, M.Z., Bornet, B., Balatti, P.A. and Branchard, M. 2003. Inter simple sequence repeat (ISSR) markers as a tool for the assessment of both genetic diversity and gene pool origin in common bean (Phaseolus vulgaris L.). Euphytica, 132: 297-301.

Pimenov, M.G. and Leonov, M.V. 1993. The genera of the Umbelliferae. Royal Botanic Gardens, Kew, U.K.

Pimenov, M.G., Kljuykov, E.V. and Ostroumova, T.A. 2007. Critical taxonomic analysis of Dichoropetalum, Johrenia, Zeravschania and related genera of Umbelliferae- Apioieae- Peucedanea. Willdenowia 37:465- 601.

Plunkett, G.M. and Downie, S.R. 1999. Major lineages within Apiaceae subfamily Apioideae: a comparison of chloroplast restriction site and DNA sequences data. Am. J. Bot. 86: 1014-1026.

Rechinger, K.H. 1987. Johrenia. in: Flora Iranica. Rechinger, K.H. \& Hedge, I.C. (eds.), Vol. 162: 374-379. Akademische Druck and Verlagsanstalt, Graz, Austria.

Rohlf, F.J. 1992. NTSYS-pc: Numerical taxonomy and multivariate analysis system, version 2.0-State Uni. New York, Stony Brook, NY.

Sambrook, J., Fritsch, EF. and Maniatis, T. 1989. Molecular cloning: a laboratory manual, 2nd edn. Vols. 13, Cold Spring Harbor Laboratory press, Cold Spring Habor, New York.

Tutin, T.G. 1968. Johrenia DC. in: Flora Europaea. Tutin, T.G., Heywood, V.H., Burges, N.A., Moore, D.M., Valentine, D.H., Walters, S.M. \& Webb, D.A. (eds.), Vol. 2: 358, Cambridge: Cambridge Univ. press.

Zohary, M. 1973. Geobotanical Foundations of the Middle East. Vol. 1, Stuttgart.

(Manuscript received on 25 May, 2009; revised on 8 July, 2010) 